\title{
Poverty and food security analysis of handloom weaver households in a selected area of Bangladesh
}

\author{
$\bowtie$ Mohammad Ataur Rahman and S.M. Mehedy Hasan Noman
}

Department of Agricultural Finance, Bangladesh Agricultural University, Mymensingh-2202, Bangladesh

\begin{tabular}{|c|c|}
\hline ARTICLE INFO OPEN ${ }^{\text {Access }}$ & Abstract \\
\hline $\begin{array}{l}\text { Article history: } \\
\text { Received : 01 January } 2019 \\
\text { Accepted : 07 March } 2019 \\
\text { Published: } 31 \text { March } 2019 \\
\end{array}$ & \multirow{3}{*}{$\begin{array}{l}\text { Handloom industry is the most important cottage industry in Bangladesh but many of the handloom } \\
\text { weavers are in vulnerable situation. Poverty and food security are intricately interlinked and it should be } \\
\text { analyzed in different dimensions. This study was conducted to assess the calorie intake level, determine } \\
\text { the factors influencing calorie intake and identify the problems faced by the handloom weaver households } \\
\text { in a selected area of Bangladesh. A sample size of } 100 \text { households was selected randomly from six } \\
\text { villages. Data were collected through field survey by using pre-designed and pre-tested interview } \\
\text { schedule. To assess the per person per day calorie intake level of the sample household's members, the } \\
\text { food consumption data of seven days was measured by standard value of } 100 \text { gm each food item. To } \\
\text { determine the factor influencing calorie intake multiple regression analysis was carried out. Calorie intake } \\
\text { level and food consumption scores were used to measure poverty and food security. According to calorie } \\
\text { intake level } 15 \text { percent of the handloom weavers belonged to hardcore poor whose average calorie intake } \\
\text { was } 1698.13 \mathrm{k} \text {.cal, and } 46 \text { percent weaver belonged to absolute poor whose average calorie intake was } \\
2078.36 \mathrm{k} \text {.cal, and the rest } 39 \text { percent of the respondents belonged to non-poor whose average calorie } \\
\text { intake was } 2251.77 \mathrm{k} \text {.cal. Food consumption scores unveiled that } 6 \text { percent weaver households had poor } \\
\text { food consumption while } 39 \text { percent weaver households had borderline food consumption; } 31 \text { percent had } \\
\text { acceptable low food consumption and } 24 \text { percent weaver households had acceptable high food } \\
\text { consumption. Income of the household and cultivable area have positive impact on calorie intake of the } \\
\text { household's members. Among the reported problems low wage rate was ranked the main problem faced by } \\
\text { the handloom weavers. Bangladesh Handloom Board, government and non-government organizations, and } \\
\text { institutions can take specialized policies for handloom weavers to reduce poverty and strengthen food } \\
\text { security. }\end{array}$} \\
\hline $\begin{array}{l}\text { Keywords: } \\
\text { Poverty, Food Security, Handloom } \\
\text { Weaver, Bangladesh }\end{array}$ & \\
\hline $\begin{array}{l}\text { Correspondence: } \\
\text { Mohammad Ataur Rahman } \\
\text { 凶: marahman@bau.edu.bd }\end{array}$ & \\
\hline
\end{tabular}

\section{Copyright:}

(c) (i)

(C2019 by authors and BAURES. This work is licensed under the Creative Commons Attribution International License (CC By 4.0).

\section{Introduction}

Handloom industry in Bangladesh is having splendid history, uncertain present and indistinct future due to various factors that are acting behind the scene. Handloom industry is the largest handicraft industry in Bangladesh; it is the second leading source of rural employment after agriculture (Ahmad, 1999). There are about 183512 handlooms weaving units with about 505556 looms. The total equipped looms are 311851, which are about $68 \%$ of total looms, and the rest 193705 looms are outdated in Bangladesh (Liton et al. 2016). But now, handloom industry in Bangladesh faces many challenges. Number of handlooms decrease day by day. Besides this, due to extreme competition with lucrative power loom, the number of unneeded loom increases. Handloom industry in Bangladesh contributes about $63 \%$ of the total cloth production in the country designed for domestic consumption as well as export, meeting $40 \%$ of the domestic demand for fabrics, it also provides employment opportunities to thousands of rural male and female. Handloom industry plays crucial role to reduce poverty and increase households' income and expenditure in the country. Therefore, in Bangladesh, handloom sector has heartening role to solve unemployment problem and economic development (Liton et al. 2016).
Poverty alleviation is the center issue in the development dialogue (Rahman, 2006). With others areas, end poverty in all its forms everywhere, end hunger, achieve food security and improved nutrition of the citizen of a country are the focused areas in Sustainable Millennium Development Goals (SDGs). If we need to achieve the SDGs by 2030, we need to focus on poverty of all groups of people considering the importance of " poverty analysis should focus on an individual's potential to function rather than the results the individual obtains from functioning" (Sen,1999b). Handloom weavers' poverty should be seen as the deprivation of basic capabilities rather than merely as lowness of incomes, which is the standard criterion of identification of poverty; the instrumental relation between low income and low capability is variable between different communities and even between different families and different individuals (Sen,1999a).

Poverty and food insecurity have been prime disquiet in the recent times in Bangladesh (Rahman et al. 2013). Poverty and food security of handloom weavers are essential areas need to give attention for improvement of their livelihood. Sustainable development and food security in poor countries cannot succeed in the longterm without qualified individual poverty analysis (Bryant, 2005). When we discuss about the food 
security, we need to consider all the elements of food security such as availability, accessibility, utilization and sustainability. So, ensuring food security for everyone is very complex and difficult which Bangladesh faces nowa-days.

In spite of considerable achievements in food availability through food grain production, food security at all levels such as national, household and individual remains an issue of most important fear for the government of any country. Regardless of the increase in food production and its availability, food insecurity as well as poverty is still a key problem mainly because of not having purchasing power particularly for the poorest group of people. Poverty rate has dropped to 24.3 percent. According to the latest survey results, the poverty rate in rural areas was 26.4 percent, while urban poverty was 18.9 percent (HIES, 2016). The current rate of extreme poverty is 12.9 percent, compared to 17.6 percent six years ago (BBS, 2017). A huge number of households keep their food consumption to a small number of food groups, namely cereals (mainly, rice), wheat, oil, vegetables, and fish. The consumption of this food basket is insensitive to poverty status, that is, households across all poverty strata consume a similar mix of food groups. In general, while households' consumption of meat products, milk, and eggs is limited, higher income groups are more likely to consume fruits and meat products (Rabbani, 2014).

We can see from HEIS, 2016 and BBS, 2017 reports that Bangladesh is a right way to trim down poverty and attain food security for its citizens. As a large number of labor forces are engaged in handloom industry in Bangladesh (Ahmad, 1999). If we can identify their poverty, food security situation and problems faced by the handloom weavers, we can make proper policy for them. Considering those facts the major research questions were; what are their food consumption level? What factors influencing their consumption? and what are the problems faced by the them regarding handloom operations? On the basis of the research questions, this research was focused on to measure the calorie intake level of the sample households' members, identify factors influencing calorie intake, and to analyze the problems faced by the handloom weaver regarding handloom industry.

\section{Materials and Methods}

Handloom industry did not develop equally in all regions of Bangladesh. It is intense in some areas where inputs are available, easy to marketing and infrastructure facilities. Sirajgang district has the highest number of establishments (Liton et al. 2016) (see Appendix-I). For this reason, Sirajganj district was purposively selected for this study. The study was conducted in six villages namely: Kaizuri, Sonatola and Gudhibari from Shahzadpur upazila and Pachlia, Raninagar and Tarutia under Ullapara upazila. Random sampling was applied for sample selection for conducting the field survey. A total of 100 weavers were interviewed using predesigned interview schedule. The respondents were briefed about the objectives of the study before going to make actual interview. Interviews were normally taken place at the weavers' house in their leisure time. At the time of interview, questions were asked systematically and explained whenever, it was felt necessary. Weavers usually do not keep any records of day to day transaction of their daily life and weaving activities. In order to minimize errors, data were collected in local units. However, these local units were later converted into standard international units at the time of data processing.

To assess the calorie intake level of the sample households' members, the consumption data of handloom weaver households of seven days was measured by standard value of $100 \mathrm{gm}$ each food item. For the calculation, family members are defined as one adult male and one adult female is $1: 1$, the child whose age is below 5 years considered as zero and $5-10$ years considered as half of an adult member.

To estimate the factors influencing calorie intake the specified regression model (Gujrati,1995) has been developed as follows:

$\mathrm{C}=\alpha_{+} \beta_{1} \mathrm{I}+\beta_{2} \mathrm{E}+\beta_{3} \mathrm{~A}+\beta_{4} \mathrm{~F}+\beta_{5} \mathrm{C}+\mu_{\mathrm{i}}$

Where,

$\mathrm{C}=$ Calorie intake per day per person

$\alpha \quad=$ Constant term

I = Income of the household

$\mathrm{E} \quad=$ Education level of the respondent

$\mathrm{A}=$ Age of the respondent

$\mathrm{F} \quad=$ Family size

$\mathrm{C}=$ Cultivable Area

$\mu_{\mathrm{i}} \quad=$ Error term

\section{Food Consumption Scores (FCS)}

In order to measure food security, food consumption score (FCS) was used in this study (WFP, 2009). In the Table 1 describes the food groups and their weight through calculation steps.

Table 1. Food groups and their weight

\begin{tabular}{clcc}
\hline & Food items (examples) & $\begin{array}{c}\text { Food groups } \\
\text { (definitive) }\end{array}$ & $\begin{array}{c}\text { Weight } \\
\text { (definitive) }\end{array}$ \\
\hline 1 & Maize, maize porridge, rice, sorghum, millet pasta, bread and other cereals & Main staple & 2 \\
& Cassava, potatoes and sweet potatoes, other tubers, plantains & \\
2 & Beans. Peas, groundnuts and cashew nuts & Pulse & 3 \\
3 & Vegetables, relish and leaves & Vegetables & 1 \\
4 & Fruits & Fruit & 1 \\
5 & Beef, goat, poultry, pork, eggs and fish & Meat and fish & 4 \\
6 & Milk yogurt and other diary & Milk & 4 \\
7 & Sugar and sugar products & Sugar & .5 \\
8 & Oils, fats and butter & Oil & .5 \\
9 & Spices, salt, fish power, small amounts of milk for tea. & Condiments & 0 \\
\hline
\end{tabular}

Source: WFP, 2009 


\section{Bangladesh Specific FCS Threshold}

Given the significance of oil and fish in the diet of the Bangladeshi people, these thresholds were elevated (WFP, 2009). As a result, FCS thresholds were revised for Bangladesh and four food consumption groups were created:

- Poor consumption $(\leq 28)$,

- Borderline Consumption ( $>28$ and $\leq 42)$,

- Acceptable Consumption (>42).

- An additional threshold was introduced to distinguish the acceptable households between acceptable low (43-52) and acceptable high (>52).

To compare the food security status of handloom weavers on the basis of national level indicator the testing procedure was as follows:

\section{Proportion Test}

The null and alternative hypotheses are:

$\mathrm{H}_{0}: \mathrm{P} \leq \mathrm{P}_{0}$ vs $\mathrm{H}_{1}: \mathrm{P}>\mathrm{P}_{0}$

$\mathrm{H}_{0}$ is the null hypothesis that the proportion is $\mathrm{P}_{0}$

$\mathrm{H}_{1}$ is the alternative hypothesis that the proportion is $\mathrm{P}$

Under the null hypothesis the test statistics is

$$
\text { Zcal }=\frac{\mathrm{P}-\mathrm{P}_{0}}{\sqrt{\mathrm{p}_{0} \mathrm{q}_{0} / n}}
$$

Where, $\mathrm{q}_{0}=1-\mathrm{p}_{0}$

Where, $\mathrm{p}=$ sample proportion

$\mathrm{p}_{0}=$ hypothesize population proportion

$\mathrm{n}=$ sample size

If $\mathrm{Zcal} \geq \mathrm{Z}_{\alpha}$, null hypothesis can be rejected at $\alpha \%$ level of significance, otherwise accepted (Rahman et al. 2016).

\section{Results and Discussion}

\section{Calorie Intake}

Considering the amount of food consumed by the respondents and their family members per person perday calorie intake was calculated. The sample households were asked about their last 7 days food consumption amount like how much rice, fish, meat vegetables, how many eggs, fruits consumed. After collecting that information we converted all the consumed food amount into calorie, then we calculated per capita per person calorie intake level. It was classified into the following four categories in Table 2.

Table 2. Calorie intake by the sample households

\begin{tabular}{lcc}
\hline Categories & $\begin{array}{c}\text { Number of } \\
\text { respondents }\end{array}$ & $\begin{array}{c}\text { Per Person Per day } \\
\text { Average Calorie } \\
\text { Intake (k.cal) }\end{array}$ \\
Ultra Poor $(<1600 \mathrm{kcal})$ & 0 & - \\
Hardcore Poor $(<1805 \mathrm{kcal})$ & $15(15 \%)$ & 1698.13 \\
Absolute Poor $(<2122 \mathrm{kcal})$ & $46(46 \%)$ & 2078.36 \\
Non- Poor (Above $2122 \mathrm{kcal})$ & $39(39 \%)$ & 2251.77 \\
\hline
\end{tabular}

Source: Authors Estimation. Figures within parentheses indicate percentages of total.

There was no respondent belonged to ultra poor $(<1600$ k.cal). About $14 \%$ of the respondents belonged to hard core poor $(<1805 \mathrm{k} . \mathrm{cal})$ whose average calorie intake was $1698.13 \mathrm{k} . c a l$ and $46 \%$ of the respondents had an average calorie intake $2078.36 \mathrm{k}$. calories and they belonged to absolute poor. The rest $39 \%$ of the respondents took above $2122 \mathrm{k.cal}$. and average calorie was $2251.77 \mathrm{k}$.cal. Therefore, the maximum number of respondents belonged to the hard core poor.

\section{Individual Food Intake}

Food consumption vary one group to another. This section compared the food consumption level of handloom weavers with national average. Per capita per day food consumption of handloom weaver was presented in Table 3. The table reflects that rice was the highest amount of food intake which was $588.39 \mathrm{gm}$ per person per-day and it was $72.23 \mathrm{gm}$ more than the national average. The table reveals that the weavers consume wheat, meat and egg less than the national average. Per capita per day fish intake was $94.38 \mathrm{gm}$ household level while it was $44.65 \mathrm{gm}$ at national level. They consumed fish $49.73 \mathrm{gm}$ more than that of national level because of availability and affordable price of fishes. They also consumed pulse, milk and fish more than the national level average consumption. From above comparison we can observed that some food items like wheat, meat and egg were consumed less than national average. If the government policy is to ensure food and nutritional security of all group of people in Bangladesh, policies should be formulated on the basis of the local demand.

Table 3. Food intake per person per day

\begin{tabular}{lccc}
\hline $\begin{array}{l}\text { Major } \\
\text { food items }\end{array}$ & $\begin{array}{c}\text { Per person per } \\
\text { day food intake } \\
\text { (gm/person/day) }\end{array}$ & $\begin{array}{c}\text { National Average per } \\
\text { person per day food } \\
\text { intake } \\
\text { (gm/person/day) }\end{array}$ & $\begin{array}{c}\text { Difference } \\
\text { between } \\
\text { national } \\
\text { average }\end{array}$ \\
\hline Rice & 588.39 & 516.16 & +72.23 \\
Wheat & 15.28 & 45.21 & -29.93 \\
Potato & 151.15 & 96.45 & +54.70 \\
Vegetables & 120.33 & 109.58 & +10.75 \\
Pulses & 15.92 & 9.86 & +6.06 \\
Meat & 12.41 & 23.24 & -10.83 \\
Egg & 5.18 & 8.03 & -2.85 \\
Milk & 32.76 & 21.64 & +11.12 \\
Fish & 94.38 & 44.65 & +49.73 \\
\hline
\end{tabular}

Source: Field Survey, 2017

\section{Food Consumption Scores}

Food consumption scores of sample household were presented in Table 4 . There were 6\% household having poor food consumption and $39 \%$ having borderline food consumption. About 31\% weaver households had satisfactory low food consumption and only $24 \%$ households have satisfactory high food consumption.

\section{Factors Influencing Calorie Intake}

The independent variables used in explaining the caloric intake function were household's income, education of the respondent, age of the respondent, family size and cultivable land area. All the independent variables influenced on food consumption by the handloom weaver households. Co-efficient of multiple determination $\left(\mathrm{R}^{2}\right)$ indicated the total variations of output explained by the independent variables; F-value was used to measure the goodness of fit for different types inputs. 
Table 4. Percentage of food consumption score by the sample household

\begin{tabular}{lcc}
\hline Profiles & $\begin{array}{c}\text { No. of } \\
\text { respondents }\end{array}$ & $\begin{array}{c}\text { \% of } \\
\text { total }\end{array}$ \\
\hline Poor consumption $(\leq 28)$ & 6 & 6 \\
Borderline Consumption $(>28$ and $\leq 42)$ & 39 & 39 \\
Acceptable Consumption low $(43-52)$ & 31 & 31 \\
Acceptable Consumption high $(>52)$ & 24 & 24 \\
Total & 100 & 100 \\
\hline
\end{tabular}

Source: Field Survey, 2017

Table 5 indicates that the intercept term was positive. The intercept in a multiple regression model is the mean for the response when all of the explanatory variables take on the value 0 . The value of the coefficients of income of the household, education of respondent and cultivable area of the respondent were positive with individual calorie intake. The handloom weaver households who had more income they purchased more foods and consumed more. Similarly, the respondents who were more educated they had more knowledge about the nutrition of the food items and consumed more nutritious foods, and the respondents who had more cultivable area they produced more foods in their field as a results, their own foods were more that leads to more food consumption. On the other hand, age of the respondent and family size of the household coefficients were negative with individual calorie intake. The respondents whom age was more they were not so interested to buy more foods for their family that leads to negative calorie intake. Similarly, when family size was large, share of the limited food items was small.

Table 5. Estimated coefficients and related statistics of the linear regression

\begin{tabular}{lcc}
\hline Variables & Coefficient & t-values \\
\hline Constant & $1208.48 * *$ & 17.643 \\
Income of the household & $0.0101 * *$ & 8.687 \\
Education level of the respondent & 5.51 & 0.527 \\
Age of the respondent & -1.9 & -0.624 \\
Family size & -15.86 & -1.029 \\
Cultivable Area & $0.897 *$ & 3.079 \\
$\mathrm{R}^{2}$ & 0.690 & \\
Adjusted $\mathrm{R}^{2}$ & 0.669 & \\
$\mathrm{~F}$ & $90.431^{* *}$ & \\
$* *$ and * indicate significances at 0.01 and 0.05 probability level, \\
respectively.
\end{tabular}

\section{Problems Faced by the Weavers}

The weavers were having a variety of challenges like capital constraint, incapability to acquire modern machineries, unfavorable working environment, low wages, increased price of input, lack of government support, not have of adequate domestic market and domestic demand (Roy and Chouhan, 2017).

Food security of handloom weaving households is hampered as weavers face many problems pertaining to the weaving, their working environment and payment (Mamidi et al., 2017). In this research, the handloom weavers faced five types of problems such as: low wage rate, no overtime payment, health risk, unhealthy working environment, and delay payment of wage were found. However, this sector was faced with various problems, such as outdated machinery, indecent production structure, low output, insufficient operational capital, usual product variety, and fragile marketing links. Further, handloom sector has always been a weak competitor against power-loom and mill sectors (Raju and Rao, 2014).

Wage was usually paid to the weavers on weekly basis. Weavers work on a fixed wage rate, which was very low according to them and comparing with other works. About $45 \%$ weavers claimed low wage rate as their first problem, which was maximum while $34 \%, 11 \%, 4 \%$ and $6 \%$ weavers ranked low wage rate as their second, third, fourth and fifth problem, respectively. So, it obviously was weavers' top problem according to Table 6. Handloom weavers income was very low; it was very difficult for them to survive in the inflationary market economy. It was very high time to review their wages (Jahan and Kumkum, 2016). About 48\% weavers voted no overtime payment as their fifth problem; this was the maximum percentage for this problem. The table also reveal that, $6 \%, 16 \%, 12 \%$ and $18 \%$ weavers thought that no overtime payment is their first, second, third, and fourth problem, respectively. Health risk of the handloom weavers was another problem. About 31\% weaver claimed it was their third problem, whereas $12 \%, 12 \%, 30 \%$ and $15 \%$ weavers said it was their first, second, fourth and fifth problem, respectively. About $34 \%$ weavers ranked bad working environment as their fourth problem whereas $9 \%, 18 \%, 24 \%$, and $15 \%$ weavers claimed it was their first, second, third and fifth problem, respectively. Delay payment of wage was another problem for handloom weavers. About $20 \%$ of the weavers reported it was their second problem, whereas $28 \%, 22 \%, 14 \%$ and $16 \%$ weavers reported it was their first, third, fourth and fifth problem, respectively.

Table 6. Ranking of problems faced by weavers

\begin{tabular}{lcccccc}
\hline Problem & \multicolumn{5}{c}{ Number of times problem was ranked } \\
\cline { 2 - 7 } & First & Second & Third & Fourth & Fifth & Total \\
\hline Low wage rate & 45 & 34 & 11 & 4 & 6 & 100 \\
No overtime payment & 6 & 16 & 12 & 18 & 48 & 100 \\
Health risk & 12 & 12 & 31 & 30 & 15 & 100 \\
$\begin{array}{l}\text { Bad working } \\
\text { environment }\end{array}$ & 9 & 18 & 24 & 34 & 15 & 100 \\
$\begin{array}{l}\text { Delay payment of } \\
\text { wage }\end{array}$ & 28 & 20 & 22 & 14 & 16 & 100 \\
\hline
\end{tabular}

Source: Field Survey, 2017

\section{Proportion Test: Compare to National Level}

$\mathrm{H}_{0}: \mathrm{P} \leq .243 \mathrm{VS} \mathrm{H}_{1}: \mathrm{P}>.243$

The test statistic is $\begin{aligned} Z & =\frac{P-P_{0}}{\sqrt{\frac{\mathrm{p}_{0} \mathrm{q}_{0}}{\mathrm{n}}}} \\ & =\frac{61-0.243}{\sqrt{\frac{0.243 \times .757}{200}}}=8.55687\end{aligned}$ 
At $5 \%$ level of significance, We may conclude that $\mathrm{H}_{0}$ can be rejected.

Now, Though government say that $24.3 \%$ citizen of the Bangladesh are poor, for handloom weavers, the value was significantly high that was $61 \%$.

\section{Conclusion}

Achieving food security for all of the citizens is one of the most important challenges for present Bangladesh. The study found that most of the handloom weaver households were living with poverty and food insecurity. Majority of them were absolute poor and hard core poor having poor and average food consumption. It could be concluded from the above discussion that they were very poor and they were suffering from food insecurity. Considering the national average food consumption, it was found that the weaving households had wheat, meat and egg less than the national average consumption whereas rice, vegetables, potato, pulses, milk and fish had more than the national average consumption.

The handloom weavers were facing different problems such as low wage rate, no overtime payment, health risk, unhealthy working environment, and delay payment. For ensuring food security and reducing poverty of handloom weavers policy maker should formulate the wage rate policy for the handloom weavers on the basis of their expenditure on basic needs. As the weavers worked more than their daily working hours, they should be paid by the handloom owners as an overtime. If the handloom owners are not agree on this, the government should take necessary action on this. The handloom owners should take care the handloom weavers when they are injured in their working place. Every worker has right to have healthy working environment. For ensuring the healthy working environment, government should make monitoring cell for the handloom industry. Most importantly, payment should be on time. As the weavers are poor, they are waiting for their salary after end of the payment date, if they could not get their salary on time they are not able to buy their daily needs. So, the government and others relevant authorities should focused on those problems.

\section{References}

Ahmed, M.U. 1999. Development of small scale industries in Bangladesh in the new millennium, challenges and opportunities. Journal of Asian Affairs, 21(1): 24-28.

BBS 2005. Report on Bangladesh handloom census, 2003. Bangladesh Bureau of Statistics, Planning Division, Ministry of Planning, Govt. of the People's Republic of Bangladesh.
BBS 2017. Report on Bangladesh handloom census, 2003. Bangladesh Bureau of Statistics, Planning Division, Ministry of Planning, Govt. of the People's Republic of Bangladesh.

Bryant, E. 2005. Building local skills and knowledge for food security. International Food Policy Research Institute (IFPRI)

FAO 2008. Food and Agricultural Organization. Food Security Information for Action, Practical Guides. Available at: www.foodsec.org/docs/concepts_guide.pdf, Accessed on 17th May 2017.

Gujrati, D. N. 1995. Basic Econometrics. Third edition, McGraw-Hill, Inc.

HIES 2016. Reports on Household Income and Expenditure Survey, Ministry of Planning, Dhaka, Bangladesh.

Jahan, N. and Kumkum, I.J. 2016. Comparative Economic Profitability and Problems of Handloom Pro ducts of Bangladesh: A Study on Handloom Weavers of Benarashi, Jamdani, and Lungi, The Cost and Management, 44(5): 29-37.

Liton, M. R. I., Islam, T. and Saha, S.2016. Present Scenario and Future Challenges in Handloom Industry in Bangladesh, Social Sciences. 5(5): 70-76. https://doi.org/10.11648/j.ss.20160505.12

Mamidi, B.B., Nisargapriya, T. S. and Elango, R. 2017. Poverty and Inclusion in Hamdloom Sector- A Case Study of Chirala handloom Weavers. Journal of Social Work Foot Prints. https://www.socialworkfootprints.org/articles/poverty-andinclusion-in-handloom-sector-a-case-study-of-chiralahandloom-weavers

Rabbani, A. 2014. Household Food Security in Bangladesh: Going beyond Poverty Measures. Bangladesh Development Studies, Vol. XXXVII, March-June 2014, Nos. 1 \& 2, pp $103-125$.

Rahman, M.A. 2006. Capabilities and Social Networks: Poverty and Development Analysis in Selected Areas in Bangladesh (Book), Der Andere Publication, Germany. ISBN-10: 389959-536-X, ISBN-13: 978-3-89959-536-9.

Rahman, M.A., Siddiki, M. and Khan, M.A. 2016. Impact of Credit on Tribal Livelihoods and Food Security in Bangladesh. International Journal of Emerging Issues in Economics, Finance and Banking. 1(1):1793-1801.

Rahman, M.A., Abka, R., Rahman,M.S. and Sarma, P.K. 2013. Poverty and food security analysis: A study of fishermen households in a selected area of Bangladesh. Journal of the Bangladesh Agricultural University. 11(2): 293-299. https://doi.org/10.3329/jbau.v11i2.19928

Raju,G.N. and Rao, K.V. 2014. A Study on the Socio-economic Conditions of Handloom Weavers. Journal of Rural Development, 33(3): 309-328.

Roy,A. and Chouhan,P. (2017). Socio-Economic Profile and Social Well-being of Handloom Industry Weavers of Gangarampur Block in Dakshin Dinajpur District of West Bengal, India. International Journal of Research in Geography (IJRG) 3(3): 1-15. http://dx.doi.org/10.20431/2454-8685.

Sen,A. 1999a. Development as Freedom. Oxford University Press, Oxford.

Sen, A. 1999b. The Possibility of Social Choice. American Economics Review, 89(3): 349-378. https://doi.org/10.1257/aer.89.3.349

WFP 2009. World Food Programme, Food Security in Bangladesh: Papers presented in the national workshop. Ministry of food and disaster management, Government of the People's Republic of Bangladesh and World Food Programme (WFP), Bangladesh. 
Ranking of districts by handloom

\begin{tabular}{lccc}
\hline District & Establishments & Looms & Ranking \\
\hline Sirajgang & 14870 & 143858 & 1 \\
Tangail & 6476 & 37222 & 2 \\
Pabna & 7434 & 35119 & 3 \\
Narsingdhi & 7247 & 26693 & 4 \\
Kushtia & 11927 & 22348 & 5 \\
Narayangang & 5178 & 14743 & 6 \\
Dhaka & 5448 & 13604 & 7 \\
Brahmanbaria & 3944 & 10505 & 8 \\
Bogra & 3877 & 5446 & 9 \\
Comilla & 3090 & 4696 & 10 \\
Total & $69491(37.9)$ & $314234(62.2)$ & \\
\hline
\end{tabular}

Source: BBS,2005 (Handloom Census, 2003)

Note: The table excludes handloom establishments and looms in Chittagong and the figure in bracket of the last row shows the Percent of Bangladesh.

List of calories of different food items

\section{Appendix-II}

\begin{tabular}{lcc}
\hline Food items & Amount & Calorie \\
\hline Rice & $100 \mathrm{gm}$ (uncooked) & 372 \\
Flour & $100 \mathrm{gm}$ & 340 \\
Potato & $100 \mathrm{gm}$ & 77 \\
Chicken & $100 \mathrm{gm}$ & 110 \\
Beef & $100 \mathrm{gm}$ & 187 \\
Tomato & $100 \mathrm{gm}$ & 18 \\
Pulse & $100 \mathrm{gm}$ & 14 \\
Korola & $100 \mathrm{gm}$ & 17 \\
Brinjal & $100 \mathrm{gm}$ & 25 \\
Leafy Vegetables & $100 \mathrm{gm}$ & 49 \\
Egg & $1 \mathrm{pc}$ medium & 78 \\
Milk & $100 \mathrm{ml}$ & 44 \\
Fish & $100 \mathrm{gm}$ & 100 \\
Apple & $100 \mathrm{gm}$ & 52 \\
Orange & $100 \mathrm{gm}$ & 47 \\
Banana & $1 \mathrm{pc}$ medium & 105 \\
Pineapple & $100 \mathrm{gm}$ & 50 \\
Guava & $100 \mathrm{gm}$ & 68 \\
Grape & $100 \mathrm{gm}$ & 67 \\
\hline
\end{tabular}

Source: FAO, 2008 (http://www.fao.org/docrep/006/Y5022E/y5022e04.htm). 